This is an Accepted Manuscript of an article published by Taylor \& Francis Group in Legal Reference Services Quarterly on 12/14/2015, available online: http://dx.doi.org/10.1080/0270319X.2015.1102024.

\title{
Using Competitive Intelligence Instruction To Develop Practice-Ready Legal Professionals
}

\author{
Catherine A. Lemmer, JD, MS*
}

\begin{abstract}
Competitive Intelligence is the identification and use of internal and external information to inform business decisions. Integrating competitive intelligence instruction into the law school curriculum is another option to use when preparing "practice-ready" legal professionals. First, it broadens the curriculum experience beyond the courtroom with its introduction of basic corporate, regulatory, and transactional documents; and second, introduces students to the critical decision making and business development skills lawyers use to identify, investigate, and develop business leads necessary for a financially viable legal practice.
\end{abstract}

Keywords: competitive intelligence, law school curriculum, research, practice-ready

\section{Contents}

Introduction

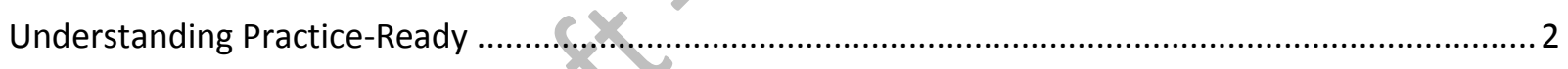

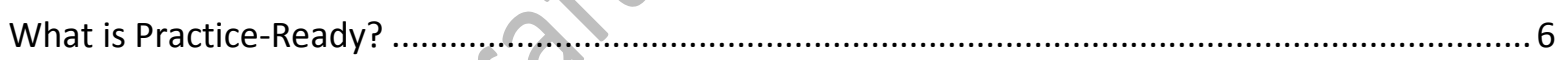

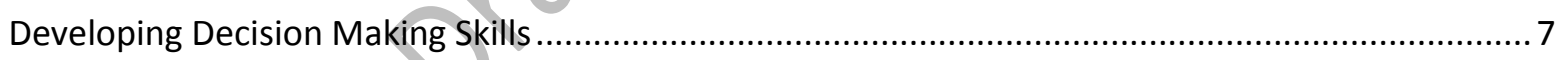

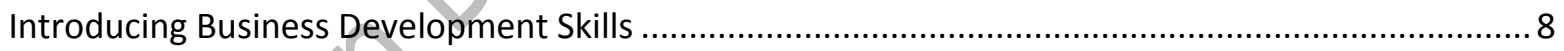

Teaching Competitive Intelligence at McKinney Law ................................................................... 11

Adding Competitive Intelligence to Second Year Legal Research: The Backstory ............................13

Competitive Intelligence at McKinney Law School Continues Its Evolution..................................... 14

The Next Level: Competitive Intelligence Instruction as a Simulation .............................................. 21

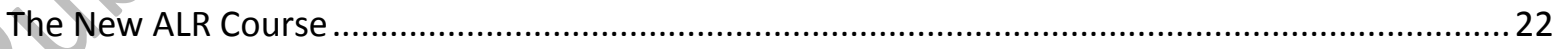

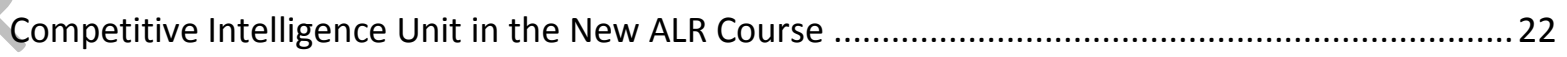

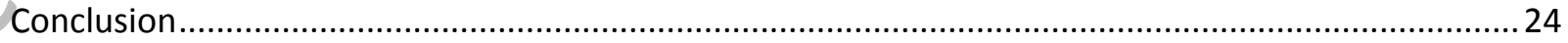

\footnotetext{
${ }^{*}$ Assistant Director - Information Services, Ruth Lilly Law Library, Indiana University Robert H. McKinney School of Law. The author wishes to thank the participants of the Seventh Annual Boulder Conference on Legal Information: Teaching \& Scholarship, held at the University of Pennsylvania Law School, Philadelphia, PA on July 16-18, 2015, for their comments and insights. Special appreciation is extended to my colleagues, Susan David deMaine and Benjamin Keele, for their support and advice. Address correspondence to Catherine A. Lemmer, Assistant Director of Information Services, Ruth Lilly Law Library, Indiana University Robert H. McKinney School of Law, 530 West New York St., Indianapolis, IN 46202-3225, USA. E-mail: calemmer@iupui.edu.
} 


\section{Introduction}

Despite robust criticism much of the law school curriculum continues its focus on case law analysis using the Socratic Langdellian teaching model. ${ }^{1}$ The overwhelming focus on appellate legal work underlying this teaching model ignores other equally important practice areas and the "how to" of building a sustainable law practice. Competitive intelligence ${ }^{2}$ instruction, delivered either as part of a legal research curriculum or as a stand-alone unit incorporated into a corporate law or business organizations course introduces students to basic corporate, regulatory, and transactional documents, and helps students develop the critical decision making and business development skills necessary to be successful lawyers. Teaching competitive intelligence serves two important goals in preparing "practice-ready" legal professionals. One, it helps students develops decision making skills in a context other than the appellate litigation practice environment; and two, it introduces students to the techniques and skills lawyers use to identify, investigate, and develop business leads necessary for a financially viable legal practice.

The first section of this article explores the current understanding of "practice-ready" and explains why a more concentrated focus on business skills is important for law students as they graduate and enter practice in today's legal environment. The following section proposes competitive intelligence instruction as a stand-alone unit that could be incorporated into a corporate law or business organizations course or included in an advanced legal research course as a viable option for delivering the practice oriented training. Section III concludes with practical advice for developing and implementing competitive intelligence instruction.

\section{Understanding Practice-Ready}

The literature on the failure of the legal academy to prepare students for legal practice is not new. In 1992, the American Bar Association's Section on Legal Education and Professional Development

\footnotetext{
${ }^{1}$ Steven D. Schwinn \& Michael A. Milleman, Why Add Real Clients and Actual Legal Work to the First-Year Curriculum in The New 1L: First-Year Lawyering with Clients 15, 15-33 (Eduardo R. C. Capulong, Michael A. Millemann, Sara Rankin \& Nantiya Ruan, eds., Carolina Academic Press, 2015).

${ }^{2}$ Competitive intelligence is a systematic three-step process that transforms random data into strategic knowledge. First, relevant external information is identified and collected. Relevant information for competitive intelligence purposes is typically data about marketplace position, historical performance, employees, executives, assets, strengths and weaknesses, and future plans. In step two, the data is analyzed and interpreted. Last, the transformed data is used to develop both short-term and long-term strategic business plans. In short it is understanding the difference between information as knowledge and information as intelligence that creates and supports actions. See Catherine A. Lemmer, Locating Company Information for Business Development and Due Diligence Purposes in Find It Fast and Free on the Net: Strategies for Legal Research on the Web 102, 99-116 (National Business Institute, 2012).
} 
published "Legal Education and Professional Development - An Educational Continuum," commonly known as the MacCrate Report. The report was the work of the Taskforce on Law School and the Profession, which had been directed to analyze the gap between the legal academy and the practicing bar. ${ }^{3}$ Proposing that professional competency is a life-long journey for lawyers, the MacCrate Report taskforce stepped back from the notion of a gap separating the duties of the legal academy and the practicing bar and advised that both entities had an equal obligation to educate and train lawyers. ${ }^{4}$ The Taskforce then identified ten fundamental lawyering skills: problem solving, legal analysis and reasoning, legal research, factual investigation, communication, counseling, negotiation, litigation and ADR, organization and management of legal work product, and recognizing and resolving ethical dilemmas. ${ }^{5}$ In 2007 a Carnegie Foundation report, "Educating Lawyers: Preparation for the Profession of Law," continued the call for legal education to align more closely with legal practice. ${ }^{6}$ Also in 2007, Roy Stuckey's "Best Practices in Legal Education" urged law schools "to do more to prepare their graduates for the jobs they are likely to have and the contexts they are likely to encounter as new lawyers." ${ }^{7}$ Stuckey encouraged the academy to reduce its reliance on the Socratic method and to incorporate a wide range of contextbased instruction methods, including problem-based learning, experiential learning, collaborative learning, simulations, clinical and internship experiences, advanced writing and research, and other skills courses. ${ }^{8}$ And if any doubt about what law student consumers need and legal employers want still existed in 2014, the issue was laid to rest by the American Bar Association's Task Force on the Future of Legal Education report stating that all law schools "have a basic societal role: to prepare individuals to provide legal and related services." ${ }^{9}$ The related amendment ${ }^{10}$ of the American Bar Association's law school

${ }^{3}$ ABA Section of Legal Educ. \& Admissions to the Bar, Legal Education and Professional Development - An Educational Continuum: Report of the Taskforce on Law School and the Profession: Narrowing the Gap (1992), http://www.americanbar.org/content/dam/aba/publications/misc/legal_education/2013_legal_education_and_pr ofessional_development_maccrate_report).authcheckdam.pdf [http://perma.cc/2L2X-DC66].

${ }^{4}$ Id. at 8 .

${ }^{5}$ Id. at 138-140 (list); full discussion of each skill found at 141-207.

${ }^{6}$ William M. Sullivan, et al., The Carnegie Foundation for the Advancement of Teaching, Educating Lawyers: Preparation for the Profession (Jossey-Bass/Wiley, 2007).

${ }^{7}$ Roy Stuckey, et al., Best Practices in Legal Education: A Vision and a Road Map 27 (2007), http://law.sc.edu/faculty/stuckey/best_practices [http://perma.cc/UF5P-AGW7].

${ }^{8}$ Id. at $132-164$.

${ }^{9}$ ABA Task Force on the Future of Legal Education, Report and Recommendations - American Bar Association Task Force On The Future of Legal Education 26 (2014), http://www.americanbar.org/content/dam/aba/administrative/professional_responsibility/report_and_recomme ndations_of_aba_task_force.authcheckdam.pdf [http://perma.cc/PL89-VYSN].

${ }^{10}$ Section 3.03(a) replaced Standard 3.02(a). The previous Standard 3.02(a) required law schools to provide certain types of "substantial instruction." Standard 302(a)(4) required substantial instruction in "other professional skills generally regarded as necessary for effective and responsible participation in the legal profession." Substantial 
accreditation standards requires that all law students complete at least six credits of experiential coursework. ${ }^{11}$ Experiential coursework must be a simulation course, law clinic, or field replacement ${ }^{12}$ which meets the identified standards. ${ }^{13}$ In amongst these publications and American Bar Association actions, have been countless conferences, speeches, blog posts, essays, and journal articles calling on law schools to develop more practice skills, transactional and negotiation training, and global and transnational law experiences.

Although law schools have responded with a variety of innovative programs, ${ }^{14}$ an objective measure of the success of these programs remains elusive. ${ }^{15}$ One measure of perceived success might be found in a survey of recent graduates and the lawyers with whom they work post-graduation. In 2015 in the first annual BARBRI State of Legal Field Survey, $76 \%$ of third-year law students reported they were practice ready, but only $56 \%$ of lawyers who work with recent law school graduates believed that, in

training in professional skills was defined in Interpretation 302-3 as "instruction ... that must engage each student in skills performances that are assessed by the instructor." ABA, Standards and Rules of Procedure for Approval of Law Schools 2013-2014. Std. 302(a); Interpretation 302-3 (2013-2014), http://www.americanbar.org/content/dam/aba/publications/misc/legal_education/Standards/2013_2014_standa rds_chapter3.authcheckdam.pdf [http://perma.cc/2ZP3-VWL9].

${ }^{11}$ The new "experiential learning" requirement found in Standard 303(a)(3) requires: "one or more experiential course(s) totaling at least six credit hours. An experiential course must be a simulation course, a law clinic, or a field placement" that "integrates doctrine, skills, and legal ethics" and provides participants with opportunities for performance and self-evaluation. ABA Section of Legal Educ. \& Admissions to the Bar, Standards and Rules of Procedure for Approval of Law Schools, as concurred by the House of Delegates, Std. 303(a)(3) August 11, 2014. ${ }^{12} / d$.

${ }^{13}$ Id. stating that to satisfy the new Standard 303(a), the course must be "primarily experiential in nature and must: (i) integrate doctrine, theory, skills, and legal ethics, and engage students in performance of one or more of the professional skills identified in Standard 302; (ii) develop the concepts underlying the professional skills being taught; (iii) provide multiple opportunities for performance; and (iv) provide opportunities for self-evaluation. The Standard 302 skills referred to in Standard 303(a)(3)(i) include (a) knowledge and understanding of substantive and procedural law; (b) legal analysis and reasoning, legal research, problem-solving, and written and oral

communication in the legal context; (c) exercise of proper professional skills and ethical responsibilities to client and the legal system; and (d) other professional skills needed for competent and ethical participation as a member of the legal profession.

${ }^{14}$ Blake D. Morant, Benefits from Challenge: The Continual Evolution of American Legal Education, $64 \mathrm{~J}$. of Legal Educ. 532 (2015); Luz E. Herrera, Training Lawyer-Entrepreneurs, 89 Denver U. L. Rev. 887, 920-930 (2012) (describing a variety of new programs); Meredith R. Miller, Designing a Solo and Small Practice Curriculum, 83 UMKC L. Rev. 949 (2015); ABA, A Survey of Law School Curricula: 2002-2010 (2012) at 75-78.

${ }^{15}$ See Keith A. Findley, Assessing Experiential Legal Education: A Response to Professor Yackee, http://papers.ssrn.com/sol3/papers.cfm?abstract_id=2592684 [http://perma.cc/NG9J-TK7R], discussing Professor Jason Yackee's finding that the there is no correlation between access to experiential learning opportunities and law graduates obtaining employment in full-time law related jobs as an invalid measure of experiential learning opportunities in law school. Findley advocates that the rationale for experiential learning is "much more about effective pedagogy for adult learners (both about substance and skills) and the need to create effective lawyers, not just as beginning attorneys, but as life-long learners and reflective practitioners" (manuscript at 2). 
general, recent law school graduates were practice-ready. ${ }^{16}$ Similarly, $71 \%$ of recent law school graduates believed they possessed sufficient practice skills; in contrast only $23 \%$ of the practicing lawyers who work with recent law school graduates believed these graduates possessed sufficient practice skills. ${ }^{17}$

I propose that one reason for the significant difference between the responses of law students and practicing lawyers is because we are not teaching our students the "right" skills; or giving equal attention to the corporate and transactional context. As New York Times writer David Segal wrote, "to succeed in [today's legal] environment, graduates will need entrepreneurial skills, management ability and some expertise in landing clients. They will need to know less about Contracts and more about contracts."18 Or as Richard Susskind notes, they will need to "be more flexible, team-based, hybrid professionals, who are able to transcend legal boundaries, speak the language of the boardroom, and are motivated to draw on techniques of modern management and information technology." ${ }^{19}$

The need to focus instruction on corporate and transactional skills is reflected in the results of a 2015 survey commissioned by LexisNexis of 300 hiring partners and senior associates, who supervise new attorneys. In this survey " $95 \%$ of hiring partners and associates whose practice has a transactional focus believed that new graduates are lacking in practical transactional skills." ${ }^{20}$ The survey participants noted that " $\mathrm{t}]$ he most important skills for new transactional attorneys are to understand fundamental business and financial concepts, conduct due diligence, find forms/checklists, draft simple contracts and agreements, and locate company information. The transactional skills most lacking in newly-graduated law students included drafting substantive contracts and ancillary agreements, locating optional/alternative clauses, negotiating contracts and salient provisions and, among large firms, reading a balance sheet or basic financial statements." ${ }^{21}$ When asked to rank the importance of specific transactional skills for hiring purposes, the survey participants responded as follows:

$79 \%$ Know fundamental financial and business concepts

$76 \%$ Conduct due diligence search

$72 \%$ Understand business associations and related organizational documents

72\% Know where to find basic company information

$65 \%$ Read a balance sheet/basic financial statements

$57 \%$ Know where to find SEC filings and how to read them

\footnotetext{
${ }^{16}$ The Barbri Group, State of the Legal Field Survey, http://www.thebarbrigroup.com/files/whitepapers/220173_bar_research-summary_1502_v09.pdf [http://perma.cc/ J6UU-XPH8].

${ }^{17} / d$.

18 David Segal, What They Don't Teach Law Students: Lawyering, N.Y. TIMES (Nov. 20, 2011), http://www.nytimes.com/2011/11/20/business/after-law-school-associates-learn-to-be-lawyers.html?_r=0.

${ }^{19}$ Richard Susskind, Tomorrow's Lawyers: An Introduction to Your Future 136 (Oxford University Press, 2013).

20 LexisNexis, White Paper: Hiring partners reveal new attorney readiness for real world practice 5 (2015), http://www.lexisnexis.com/documents/pdf/20150325064926_large.pdf [http://perma.cc/JSJ7-QV39].

${ }^{21} / d$. at 6.
} 
$54 \%$ Stay current on business news ${ }^{22}$

In the rush to create practice-ready law graduates, the legal academy has focused too often on adding more writing and experiential learning through litigation-based clinics and externships and internships, which do not focus on higher decision making skills or business development skills, and do not address the basics of corporate and transactional law practice. ${ }^{23}$ In addition, these law school experiences often exist in silos, separate from the doctrinal courses and taught by non-tenure-track voting law faculty, ${ }^{24}$ creating an appearance of less importance and lesser value. ${ }^{25}$

\section{What is Practice-Ready?}

What does practice-ready mean? As a law school graduate in the 1980s, I joined a large Chicago law firm where I immediately had the benefit of lawyers who provided feedback that improved my work product, and opportunities to attend client meetings and participate in negotiations. I prepared federal and state regulatory filings for agencies such as the Securities and Exchange Commission, the Federal Reserve Bank, and the Federal Deposit Insurance Corporation. I drafted and reviewed transaction documents, prepared an organization's formation documents and governance materials, and attended and coordinated transaction closings. I worked in and managed teams. Great mentors educated and coached me on everything from managing clients to effectively working with my administrative assistant to negotiating firm politics. ${ }^{26}$ In this environment I became practice ready, or in other words, I added problem solving, work place skills, client management, and decision making skills to the analytical casebased reasoning skills I mastered in law school. In short, my law school and early practice experiences reflected the educational concerns of the MacCrate Report and the Carnegie Report. Although my law school did not prepare me for the real world, my first work experience did. ${ }^{27}$

22 Id.

${ }^{23}$ Neil J. Dilloff, Law School Training: Bridging the Gap Between Legal Education and the Practice of Law, 24 Stan. L. \& Pol'y Rev. 425, 428 (2013).

${ }^{24}$ Kathryn Fanlund, Producing Better Prepared Graduates, Am. Ass'n Law Schools Newsletter 9 (Apr. 2015).

${ }^{25}$ Catherine A. Lemmer, A View from the Flip Side: Using the "Inverted Classroom" to Enhance the Legal Information Literacy of the International LL.M. Student, 105 Law Libr. J. 461, 468-469 (2013) discussing the "hidden curriculum" phenomena.

${ }^{26}$ As a first generation student I found this mentoring and feedback invaluable.

27 See MacCrate Report, supra note 3, at 5 stating that many practicing lawyers believe that their law school education "left them deficient in skills that they were forced to acquire after graduation." See William Hornsby, Challenging the Academy to a Dual (Perspective): The Need to Embrace Lawyering for Personal Legal Services, 70 Maryland L. Rev. 420, 436 (2011) (stating "law school graduates are ill-prepared for the future they are most likely to pursue"). 
Today's law firms no longer take on and manage this burden for a variety of reasons including, among others, reduced profits due to competition from non-legal entities and para-professionals; ${ }^{28}$ clients more interested than ever in controlling outside legal costs; ${ }^{29}$ the impact of technology on routine work; ${ }^{30}$ and a lack of interest in investing in lawyers who are unlikely to stay with the firm for the long haul. ${ }^{31}$ As a result, law schools need to bring to the curriculum opportunities for students to engage in and be assessed on problem solving and decision making, and to explore and practice concepts that underlie business development and client management. Our goal as legal educators should be to "provide students with educational experiences that will make explicit the connection between theory, skills, and values so that students understand the professional context of what they are learning." 32

\section{Developing Decision Making Skills}

My objective as a law school instructor is to develop decision making skills in my students in problem-based learning situations that replicate the legal work place. I want them to develop the ability to synthesize insights from different and often conflicting information sources and design a solution that works for this particular client in the particular circumstance. As Professor James B. Levy notes, "the critical thinking and problem solving skills at the heart of 'thinking like a lawyer' are more important than ever given a job market where lawyers may increasingly find that only the most intellectually prepared get hired to handle difficult tasks that cannot otherwise be commoditized and outsourced to cheaper, non-lawyer alternatives." ${ }^{\prime 3}$

How best to accomplish this objective is the instructional challenge. How do lawyers engage with and process information? Outside the legal academy there is significant literature on how the human mind processes information and on the development of decision making skills in business executives and

${ }^{28}$ Herbert M. Kritzer, Lawyers at Work 293 (Oxford University Press, 2015); Hornsby, supra note 27, at 431-433 (discussing competition from nonprofit entities, governmental units, and for-profit companies); Susskind, supra note 19; Richard Susskind, The End of Lawyers?: Rethinking the Nature of Legal Services (Oxford University Press 2010).

${ }^{29}$ D. Casey Flaherty, Could you pass this in-house counsel's tech test? If the answer is no, you may be losing business, ABA, Legal Rebels http://www.abajournal.com/legalrebels/article/could_you_pass_this_inhouse_counsels_tech_test (Jul. 17, 2013). [http://perma.cc/B6ZZ-WUE7].

${ }^{30}$ See Susskind (2013), supra note 19 and Susskind (2010), supra note 28.

${ }^{31}$ Charles E. Lundberg \& Aram V. Desteian, How to Leave Your Law Firm and Live to Tell the Tale, 72 Bench \& B. Minn. 16, 17 (2015).

${ }^{32}$ Cynthia Batt, A Practice Continuum: Integrating Experiential Education into the Curriculum, 7 Elon L. Rev. (forthcoming 2015) (manuscript at 2-3) http://papers.ssrn.com/sol3/papers.cfm?abstract_id=2554786.

33 James B. Levy, Teaching the Digital Caveman: Rethinking the Use of Classroom Technology in Law School, 19 Chapman L. Rev. _ (forthcoming 2015) (manuscript at 4)

http://papers.ssrn.com/sol3/papers.cfm?abstract_id=2604350. (internal citations excluded) 
leaders. This literature focuses on the "human intuition" versus "fact gathering and analysis" responses in decision making by executives and leaders. Humans are "irrationally influenced by the first information received on a particular subject-it becomes, as decision researchers put it, the 'anchor' that determines and distorts how we process all subsequent data." ${ }^{34}$ In addition, humans are hardwired to see and apply patterns to force new situations into old patterns. ${ }^{35}$ The resulting big picture is this: our inability to deal with prolonged ambiguity means sustained exploration of the alternatives-the very skill needed for intelligent decision making-is lost. ${ }^{36}$ Kahneman draws a similar distinction in his work Thinking, Fast and Slow, but adds a third combined type of thinking called "intuitive expertise" that combines the speed and effortless of human intuition with the slower and more deliberate fact gathering and analysis. "Intuitive expertise" thinking occurs when an expert or experienced individual approaches a problem. This third type of thinking develops in a professional when she has an opportunity to practice in an environment that provides current and high-quality feedback. ${ }^{37}$

The best solutions to the instructional challenge of teaching decision making skills force our law students to over-ride natural inclinations to take the first answer and challenge them to process multiple alternatives to reach the best solution for the particular client. Students need to learn how to devise and advise on a "best-case" answer for a particular client through exposure to problem-based learning situations that have no clear answers; they need to learn how to locate and synthesize often conflicting information; ${ }^{38}$ and they need to learn how to present and defend a particular "best-case" answer; as well as, how to receive peer and instructor feedback.

\section{Introducing Business Development Skills}

A law partner whom I admire put it succinctly when he said, "Successful lawyers spend 90\% of their day being entrepreneurs." Although we might dispute whether $90 \%$ is an accurate data point on the spectrum, successful lawyers more closely resemble entrepreneurs than most of us like to admit. And although some law schools offer law office and practice management courses, business development is not a core course in the law school curriculum. ${ }^{39}$

\footnotetext{
${ }^{34}$ Eric Bonabeau, Don't Trust Your Gut, Harv. Bus. Rev., May 1, 2003, https://hbr.org/2003/05/dont-trust-your-gut [http://perma.cc/6LJU-N4KE].

${ }^{35}$ Daniel Kahneman, Thinking, Fast and Slow 115 (Farrar, Straus and Giroux,2011).

${ }^{36} / d$.

37 Id. at 239-244.

${ }^{38}$ Lemmer, supra note 25 , at 482.

${ }^{39}$ Richard S. Granat \& Stephanie Kimbro, The Teaching of Law Practice Management and Technology in Law Schools: A New Paradigm, 88 Chicago-Kent L. Rev. 757, 758-760 (2013) (reviewing the 2010 American Bar
} 
Networking, marketing, and business development (a/k/a building a book of business), and client relationship management are challenging and may be scary processes for law students to envision. As students they are evaluated and graded based on parameters they understand and control. Students who prepare for and are intellectually present in class, study for exams, and write the paper or complete the project in a timely and intelligent manner will likely do well. In the real world the quality and caliber of a lawyer's work is one factor among many, including many over which a new lawyer has no control. In this environment, professional success can look like an ever-distant mirage.

Many law students have little experience developing and maintaining professional and business relationships and may not realize the work, time, and skill it takes to develop and maintain such relationships. Even the vocabulary may be new to some, for example, ROI (return on investment), RFP (request for proposal), and RFI (request for information). They may "realize that marketing and business development are part and parcel of being a successful lawyer and essential to operating a successful law firm," ${ }^{40}$ but they don't necessarily know how or where to start.

The big business of developing business ${ }^{41}$ can be broken down into two separate skill sets: management of and relationship building with existing clients; and the development and generation of new business. Existing clients want more than excellent legal service, reasonable bills, and common business courtesy. ${ }^{42}$ Clients want business savvy lawyers who understand their business. ${ }^{43}$ This knowledge can run the gamut from understanding their products, share price, markets, regulatory and competitive environments, and personnel issues to management succession planning. In short, they expect their lawyers to be part of their team, watching the horizon for the good and the bad, and to be conversant in everything from ROI and EPS to factors underlying management and executive decisions.

Law students may not know it, but every lawyer knows that business generation is the key to a successful practice. Every successful solo, mid-size, or large firm has rainmakers, either home-grown or

Association survey of Law School Curricula and other surveys on the number of schools that offer law practice management and the ever-increasing need for such instruction).

40 John Remsen, Jr., The Best Way to Get New Clients? Find Their Associations and Get Actively Involved, ABA Law Practice Today (2010), http://apps.americanbar.org/lpm/lpt/articles/mkt08072.shtml [http://perma.cc/Z4257JVL].

${ }^{41}$ The importance of law firm marketing is reflected in the fact that there is a dedicated legal marketing trade association focused on educating and assisting lawyers with business development. Founded in 1985, the Legal Marketing Association has over 3,700 members with roles ranging from marketing heads/ chief marketing officers, business development directors, communications directors, law firm administrators, and lawyers, both partner and associate level. See website at: http://www.legalmarketing.org.

42 John Remsen, Jr., Ten Golden Rules to Make Your New Clients Happy, Strategies: The J. of Legal Marketing, http://www.theremsengroup.com/131 [http://perma.cc/X6NZ-BSP7].

${ }^{43}$ Dilloff supra note 23 , at 441 . See Hornsby supra note 27 , at 435. 
enticed in from government, business, or other law firms. Successful rainmakers speak the language of business, markets, and creative strategy in a way that makes the client want to partner with them to solve a problem. ${ }^{44}$ As Dilloff writes, challenging the law school curriculum to develop these skills in law students is not "advocating a course on how to do an effective TV commercial or how to create a persuasive billboard or website. Instead, it is [learning that success comes from knowing] how to navigate successfully a 'beauty contest,' what to say and what not to say, when to talk and when to listen, how to 'hear' what clients want, how to honestly demonstrate empathy and manifest an understanding of a client's problems, both legal and personal." 45 In sum, a law firm is "both a professional practice and a service business." $^{46}$ Lawyers need to successfully master both marketing and people skills to develop and maintain clients.

Law schools concerned with preparing practice-ready legal professionals will start this training in the law school. The importance of such training during law school is even more compelling for the $69 \%$ of law graduates who practice in firms of less than 10 lawyers or as solo practitioners. ${ }^{47}$ These solo and small firm lawyers are unlikely to have the benefit of firm mentoring or extensive firm resources to supplement their training in decision making and business development skills if they don't receive such training in law school.

If we agree that law students would benefit from exposure to and training in decision making in transactional and business practice arenas, and the career skills of client management and business development-where does it best fit in the law school curriculum? Rarely do law professors have extensive law firm practice. Empirical studies have found that although the vast majority of full-time tenure-track faculty hired in the mid-1970s through the late 1980s had some practice experience, the

${ }^{44}$ Patricia K. Gillette, Rainmakers: Born or Bred?, LAW PRACTICE TODAY (Aug. 14, 2015), http://www.lawpracticetoday.org/article/rainmakers-born-bred [http://perma.cc/Q76M-BVYL].

${ }^{45}$ Dilloff, supra note 23 , at 442.

${ }^{46}$ Granat \& Kimbro, supra note 39 , at 767, also noting that "starting a law firm or expanding an existing practice requires skills in defining the target market; calculating the cost of client acquisition...; and understanding which pricing model works best with that particular business."

${ }^{47} 49 \%$ are solo practitioners; $14 \%$ practice in firms of 2 to 5 lawyers; and 6\% practice in firms of 6 to 10 lawyers. ABA, Lawyer Demographic

http://www.americanbar.org/content/dam/aba/administrative/market_research/lawyer-demographics-tables2014.authcheckdam.pdf [http://perma.cc/26EL-8ZKH] (last visited June 1, 2015) (citing the 1985, 1994, 2004 and 2012 editions of The Lawyer Statistical Report, American Bar Foundation). For additional discussion of solo and small private law firm size statistics see Granat \& Kimbro, supra note 39, at 761 (noting that two out of three practitioners in the United States practice in firms with five or less lawyers). 
average was only about 5 years. ${ }^{48}$ Data from full-time tenure-track faculty hired between 1996 and 2000 revealed that the average years of experience decreased to 3.7. New hires at the top twenty-five law schools had only 1.4 years of practice experience before entering the legal academy. ${ }^{49}$ Newton's updated research for new hires between 2000 and 2009 reports the same findings and notes the following:

The amount of practical experience differed significantly by tier. For instance, for the schools in tier one, the median was only 1 year and the mean was 1.79 years; $45.6 \%$ of the entry-level tenure-track professors hired by these schools since 2000 had no prior practical experience. Conversely, for the schools in tier four, the median years of prior practical experience was 6 years and the mean was 7 years; nearly $86 \%$ of those professors had some amount of prior practical experience. ${ }^{50}$

Newton asserts that such data supports Professor Alan Watson's theory that most law faculty join the legal academy because they have a "strong distaste for the practice of law." ${ }^{11}$ If Newton's is assertion is correct, law faculty mentoring and training of law students will focus on their area of expertise - the substantive law context, and how to form a study group, prepare for class, write an exam, or apply for a judicial clerkship; skills that do not necessarily translate into developing and sustaining a successful law practice. Given this, competitive intelligence instruction is a viable and easily implemented option.

\section{Teaching Competitive Intelligence at McKinney Law}

Since the fall semester of 2010 all second-year law students at the Indiana University McKinney School of Law ("McKinney Law") take a required one-credit legal research course that builds on the first year's legal research instruction. ${ }^{52}$ The 14 -week online course is taught asynchronously in the spring, fall, and summer semesters and letter grades are awarded pursuant to the McKinney Law curve standards for required courses. The course was developed and initially taught by a team of four dual-degreed law librarians who each brought a particular research or practice specialty to the mix (i.e., health, corporate/business, copyright, and insurance litigation). Two of the original design and teaching team also

${ }^{48}$ Brent E. Newton, Preaching What They Don't Practice: Why Law Faculties' Preoccupation with Impractical Scholarship and Devaluation of Practical Competencies Obstruct Reform in the Legal Academy, 62 SOUTH Carolina L. Rev. 128 (2010). [See here for complete discussion of many other studies.]

${ }^{49}$ ld.

${ }^{50} / d$. at $129-130$.

${ }^{51}$ Id. at 130, citing Alan Watson, The Shame of American Legal Education (2d ed., Vanderplas Publishing, 2006) at 29.

${ }^{52}$ In the first year JD program, law librarians are invited by the clinical writing instructor to provide research instruction in the required Legal Analysis, Research and Communication course. The invitation is at the discretion of the writing instructor and averages three 55-minute sessions per semester. Each individual writing instructor determines the number of research sessions and the content to be delivered by the law librarian. This structure leads to inconsistency in research instruction across the student population. One of the major goals in creating the required second year research course was to resolve this inconsistency in research instruction and bring all the students to the same skill level. 
had significant private law practice experience. The course is currently co-taught by four dual-degreed law librarians with experience in health, copyright, and corporate/business law; only one of which has law practice experience.

In designing assessments we followed the advice in Best Practices to "follow the lead of other professional schools and transform their programs of instruction so that the entire educational experience is focused on providing opportunities to practice solving problems under supervision in an academic environment. [As] [t]his is the most effective and efficient way to develop professional competence." ${ }^{53}$ Since its beginning in 2010, the second-year legal research class has used basic simulations to assess student learning. That is, we sought to ask law practice questions based on hypotheticals rather than what are often called bibliographic treasure hunt questions. In addition, we expanded the area of inquiry beyond those topics typically associated only with the courtroom or litigation practice. In some semesters all the assessments relate to the same client, for example, a family-owned organic farming corporation or golf course franchise. The use of the same client lets instructors ask deeper analytical and application questions, and gradually introduce additional facts as new issues develop.

Course assessments mimic law practice situations with questions that have no "right" answer. Research hypotheticals with multiple "right" answers give students opportunities to practice "how to do more than analysis." ${ }^{54}$ The hypotheticals require students to assess the client's situation, determine relevant facts, identify solutions, and provide advice. Students move from academic classroom performance to thinking like problem-solving lawyers. ${ }^{55}$ Based on their legal and factual research, students are graded on how they advise the hypothetical client by choosing the best alternatives from a range of options and on how they explain their choices.

As I have noted in writing about the flipped classroom and problem-based learning labs, ${ }^{56}$ law professors should avoid teaching strategies that promote a "linear or step-by-step approach [to learning] as this defeats the concept of professional problems being complex and requiring a range of approaches to solve."57 "There is no point in helping students develop deep learning skills if the educational environment is giving them the message that surface ones are rewarded." 58

\footnotetext{
53 Stuckey et al., supra note 7, at 144.

54 Lemmer, supra note 25, at 481 citing Tracy A. Thomas, Teaching Remedies as Problem-Solving: Keeping it Real, 57 St. Louis U. L.J. 673, 676 (2013).

55 Id. citing Thomas at 685.

${ }^{56}$ Lemmer, supra note 25 , at 481.

${ }^{57}$ Id. citing Rita Shackel, Beyond the Whiteboard: E-learning in the Law Curriculum, 12 Queensland U. Tech. L \& Just. J. 105, 112 (2012). See also Thomas, supra note 54.

58 Id. citing Shackel at 112.
} 


\section{Adding Competitive Intelligence to Second Year Legal Research: The Backstory}

Having practiced law, I was concerned by the limited opportunities in the law school curriculum for our law students to develop fundamental decision making skills in the corporate and transactional contexts. Even more so, I was concerned by the lack of basic corporate, financial, and transactional knowledge many students exhibited. Basic accounting principles, financial terms and metrics, hands-on use and knowledge of corporate formation and regulatory reporting documents, and engagement with the financial press were relatively unfamiliar to many students. To help fill this deficit or perhaps to add a dose of reality to law school, I advocated for and developed a one-week unit on competitive intelligence and introduced it into the second year legal research course in the Fall 2012 semester.

The unit introduces the concept of competitive intelligence and its role as a business development tool. I keep it simple as the topic is given only one week in the one-credit legal research course! Students learn how successful lawyers gather and transfer data into strategic knowledge that informs and drives their planning and actions. ${ }^{59}$ The unit focuses on identifying relevant data; gathering and comparing the data in a systematic manner; and using the data to advise a client on a business opportunity. Although I note the more complex and advanced concepts of benchmarking and market analysis, we do not have time to delve deeply into those concepts in this introductory unit.

For many students this unit is the first time they have examined (or even seen) corporate organizational documents, financial statements, and regulatory filings with the Securities and Exchange Commission and relevant Secretary of State. Similarly it is the first time many have been asked to research and draw conclusions about corporate ownership, management, stock prices, corporate financial wellbeing, and business strategies. Typically the competitive intelligence unit:

- includes a brief historical overview of competitive intelligence and its roots;

- distinguishes competitive intelligence from corporate espionage;

- introduces business, corporate, government, social media, and news search engines and resources;

- discusses and demonstrates cross-checking and weighing inconsistent data;

demonstrates how to develop relationships between different data; and

includes an opportunity to advise a client on a course of action by relating data and explaining conclusions drawn from these relationships.

One of the learning objectives of the competitive intelligence unit is to encourage students to engage with and challenge the information. I want them to extrapolate the unsaid or deliberately subverted, and to ascertain the "why." I want them to question the tone of and motivation behind the

\footnotetext{
${ }^{59}$ Ann Lee Gibson, Competitive Intelligence: Improving Law Firm Strategy and Decision Making (Ark Group, 2010), citing Peter Drucker, Management Challenges for the $21^{\text {st }}$ Century (HarperBusiness, 1999).
} 
information source, as well as to identify conflicting data and resolve inconsistencies. In short, I want them to be analytical and reflective, or in other words, to adopt an attitude of "Don't believe everything you read!"60

There are a number of real-world practice examples that can be used as the basis of a hypothetical used in the assessment. The goal is to create a hypothetical that requires the students to identify and synthesize information and draw an analytical conclusion. Successful assessments are as varied as one's imagination and can easily be tailored to the law students' interests. Identifying and analyzing information for any of the following scenarios are good options:

- evaluation of estate or marital property assets;

- preparation of a client pitch letter or book;

- client report on a merger or take-over target;

- analysis of a business expansion opportunity.

Although brief, the unit develops decision making skills as students weigh competing information from a variety of sources, including basic corporate organizational and regulatory reporting documents, and advise a hypothetical client on a course of action. The unit also improves their factual investigation skills since many of the information sources are non-legal and fact-based. Introducing these materials and developing these skills in law school positions our students to better represent current clients, manage client relationships, and develop new business from existing and prospective clients once they enter the practice of law.

\section{Competitive Intelligence at McKinney Law School Continues Its Evolution}

In the 2015 summer session, I made significant revisions to the way we assessed the students in the competitive intelligence unit in the second year legal research course. The students were divided into 28 random groups of five students to produce a brief company profile on one of two Indiana-based publicly traded corporations. The excerpted scenario was as follows:

Your law firm learns that an Indiana corporation (the "Corporation") is searching for new outside counsel as the firm that currently handles much of its legal work has dissolved. The Corporation has issued a "request for proposal" (RFP). An RFP is an opportunity for your firm to detail to the Corporation its expertise and pricing strategies. However, before

60 "Do not believe in anything simply because you have heard it. Do not believe in anything simply because it is spoken and rumored by many. Do not believe in anything simply because it is found written in your religious books. Do not believe in anything merely on the authority of your teachers and elders. Do not believe in traditions because they have been handed down for many generations. But after observation and analysis, when you find that anything agrees with reason and is conducive to the good and benefit of one and all, then accept it and live up to it." - attributed to Buddha. 
the RFP can be prepared, the firm needs to better understand the Corporation and its legal needs.

Students received a checklist of the kinds of information to include, or not, based on its relevance to the corporation they were profiling. The information options included basic factual details such as state of incorporation and c-suite officers, and more complex discussions of industry trends and litigation risks. Students were cautioned that they were preparing the profile for busy lawyers and that the profile had to be more than a data dump. As such the data that the group chose to include had to be relevant to facilitating a better understanding of the corporation and its legal needs.

The assessment was graded as follows: $70 \%$ of the grade was based on the work-product (i.e., the company profile); $15 \%$ on the evaluation of a different team's company profile; and $15 \%$ on evaluations written by fellow team members. The groups were randomly assigned to replicate law practice environments (i.e., you don't get to pick your friends in a law firm) and to keep the peer-evaluations legitimate. This newly-revised assessment enabled the instructors to bring in team work and peerevaluation components to a hypothetical based in a non-litigation context.

Teamwork is itself a skill worth teaching in law school. ${ }^{61}$ Working as a collaborative team, students create one final shared product. Collaborative work produces a better final product as a result of the group's interactions ${ }^{62}$ and has a profound impact on learning. ${ }^{63}$ When students have to combine their ideas, skills, and experiences to create a shared product, they do more than master the material and produce a product. 64 "They also learn about their biases and assumptions, strengths and weaknesses, and their ability to help others succeed." ${ }^{\prime 65}$ As a result, team work develops the interpersonal, strong problemsolving, organization, communication, leadership, and team-building skills that lawyers use ${ }^{66}$ but that are not often taught in law schools. ${ }^{67}$

\footnotetext{
${ }^{61}$ See Lemmer, supra note 25, at 483.

62 Anna P. Hemingway, Accomplishing Your Scholarly Agenda While Maximizing Students' Learning (a.k.a., How to Teach Legal Methods and Have Time to Write Too), 50 Duq. L. Rev. 545, 557 (2012).

${ }^{63}$ Robin Neiforf, Teach Beyond Your Reach: An Instructor's Guide to Developing and Running Successful Distance Learning Classes, Workshops, Training Sessions, and More 168 (2d ed., Information Today, 2012).

64 Id.

65 Id.

${ }^{66}$ See Marjorie M. Shultz \& Sheldon Zedeck, Predicting Lawyer Effectiveness: Broadening the Basis for Law School Admissions Decisions, 36 Law \& Soc. Inquiry 620, 624-27 (2011) (discussing and summarizing research on the characteristics possessed by successful lawyers); Sophie M. Sparrow, Can They Work Well on a Team? Assessing Students' Collaborative Skills, 38 Wm. Mitchell L. Rev. 1162 (2012).

67 See Hemingway, supra note 62, at 558.
} 
Team members evaluated each other on their professionalism and contributions using an online peer evaluation form. The evaluation form included the following questions, and allowed students to award each other a value of 1 (poor) to 5 (excellent):

- This group member fulfilled his or her responsibilities for the project.

- This group member demonstrated creativity or thoroughness in his or her research for the project.

- This group member made a valuable contribution to the project.

Student-evaluators could also include textual comments about outstanding contributions or concerns about a team member's performance. The peer comments were anonymized and shared with the students.

Most student-evaluators awarded high marks to their colleagues. None of the 140 students in the class used the textual comments option. The overall general feedback given to all students suggested that students would have appreciated learning why they received lower ratings. In the future the assignment will encourage student-evaluators to include feedback to students with awards of " 3 " or less.

The standard McKinney Law student evaluation questionnaire (which is anonymous) was administered at the end of the 2015 summer session of the second-year legal research course. The questionnaire included the following three questions (among others that addressed other aspects of the course):

- It is likely that I will use the skills used in preparing the company profile/briefing report when looking for a job and/or when developing legal business when I start practicing.

- There was value in reviewing the company profile/briefing report of my fellow students.

- It was a valuable experience to work in random teams on the company profile/briefing report.

Students respond to the evaluation questions on a scale of 1 to 5 as follows: 1 (strongly disagree), 2 (disagree), 3 (neutral), 4 (agree), 5 (strongly agree). Space was provided on the evaluation form for students to write additional comments ("text comments"). The students in the 2015 summer legal research course were informed that the instructors were particularly interested in their feedback on the group project as it was a new assessment in the course. Out of a possible 140 responses, there were 72 responses (51.4\%). Thirteen students submitted text comments that were relevant to the group project. The results of the student evaluations ${ }^{68}$ are summarized below.

Question 1: It is likely that I will use the skills used in preparing the company profile/briefing report when looking for a job and/or when developing legal business when I start practicing.

\footnotetext{
${ }^{68} \mathrm{~A}$ copy of the summary of the standard McKinney Law anonymous student evaluation for the summer 2015 Legal Research course is on file with the author.
} 


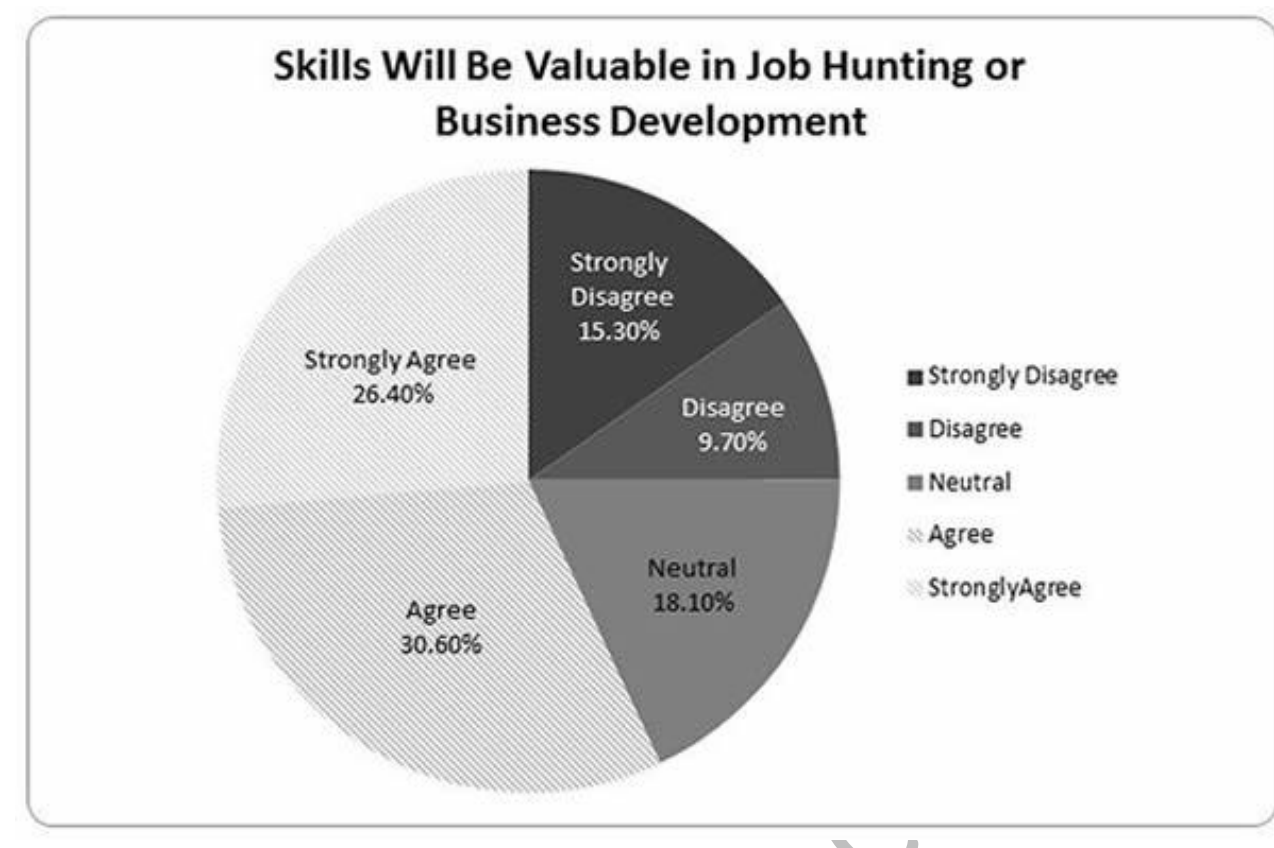

Figure 1

Responses as shown in Figure 1 above: 57\% of the students responding either agreed (30.6\%) or strongly agreed (26.4\%) that the skills assessed in the group assignment were skills they would use in either job hunting or in developing business once they started practicing law. $25 \%$ of the students responding either disagreed $(9.7 \%)$ or strongly disagreed $(15.3 \%)$ that the skills assessed would be used in job hunting or in developing business. $18.1 \%$ of the students responding expressed no opinion on the question (neutral).

Two text comments dismissed the group project as a "business" problem that had nothing to do with legal research or law. As noted above, the group project evaluated and assessed an existing Indiana corporation as a possible new client for the law firm. In the future I plan to use a hypothetical based in either a divorce settlement or will administration context. Changing the context will work to remind students that "business" is in most legal contexts and that lawyers can't leave everything to the accountants if they are going to serve their clients well. 
Question 2. There was value in reviewing the company profile/briefing report of my fellow students.

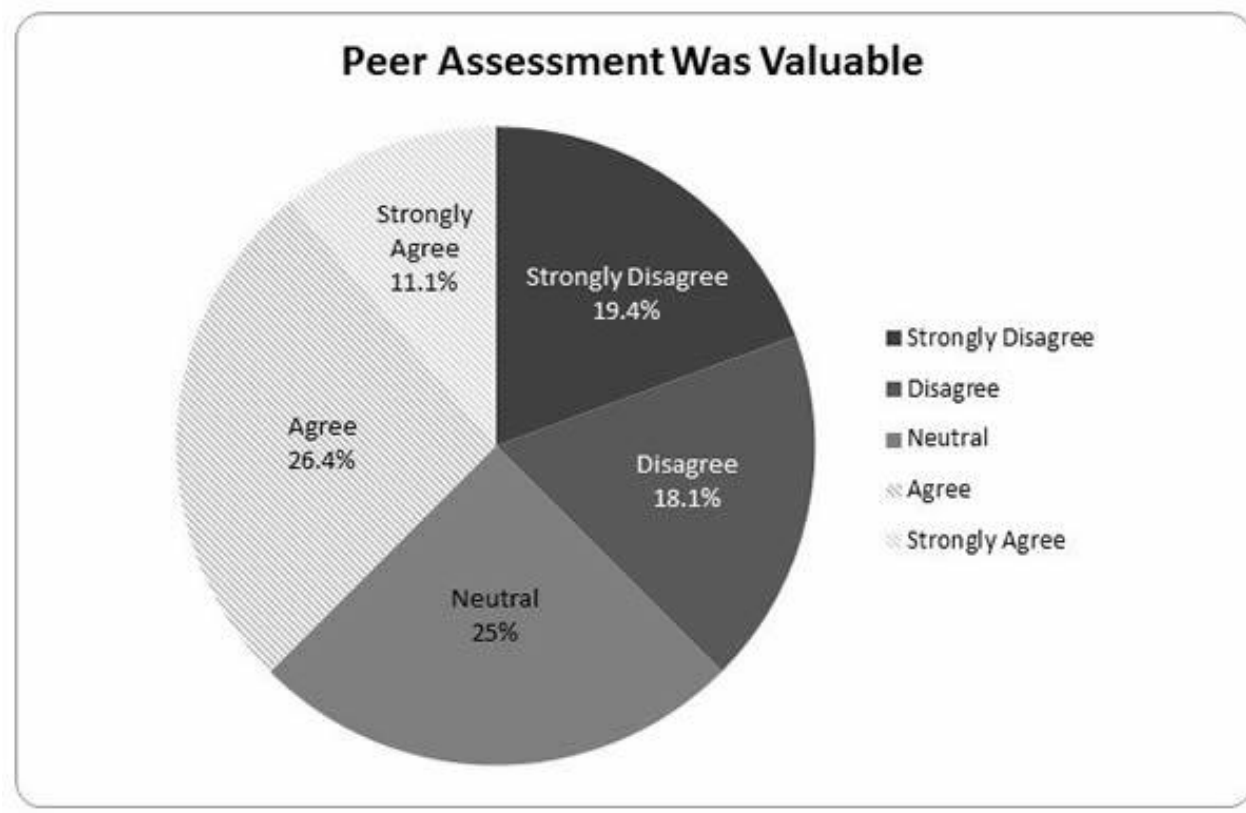

Figure 2

Responses as shown in Figure 2 above: $37.5 \%$ of the students responding either agreed (26.4\%) or strongly agreed (11.1\%) that completing the group peer evaluations was valuable. Similarly, $37.5 \%$ of the students responding either disagreed (18.1\%) or strongly disagreed (19.4\%) that completing the peer evaluations was valuable. $25 \%$ of the students responding expressed no opinion on this question (neutral). 
Question 3. It was a valuable experience to work in random teams on the company profile/briefing report.

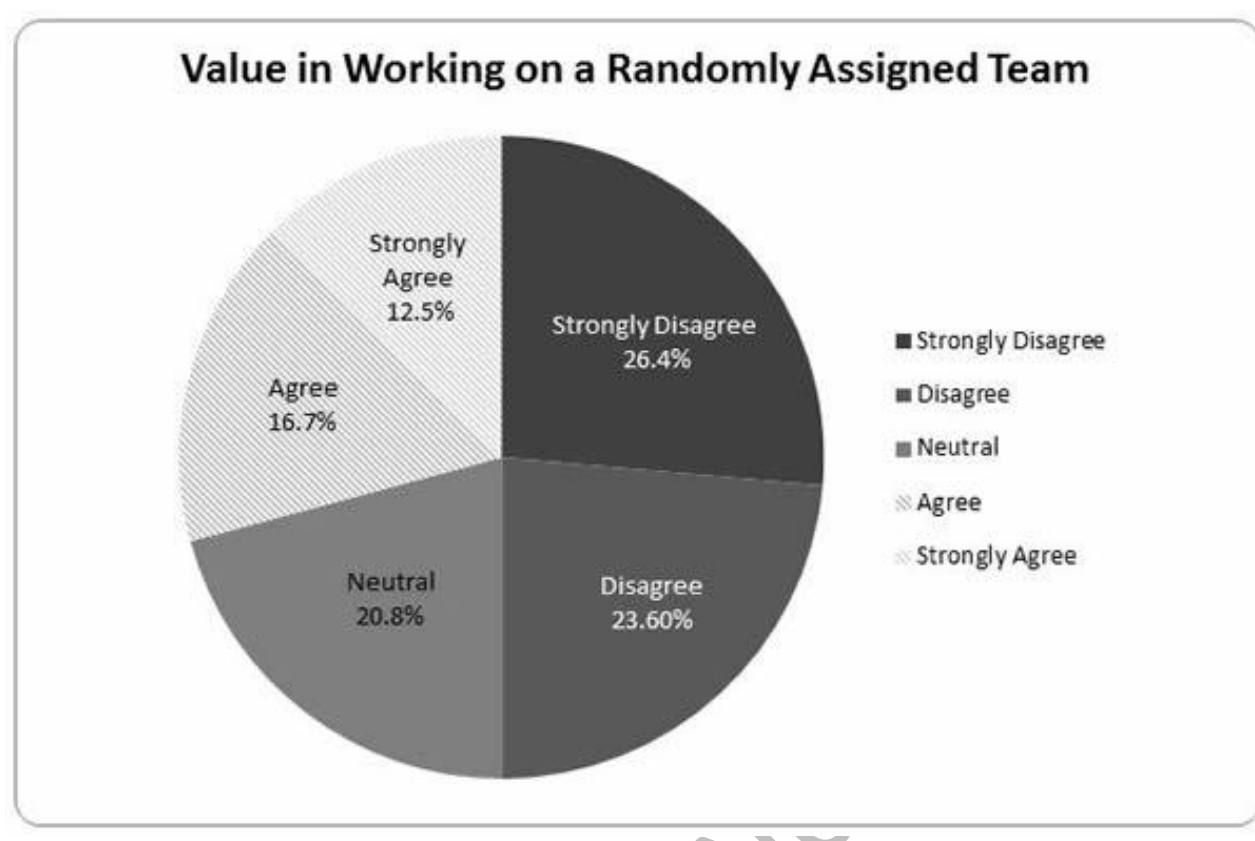

Figure 3

Responses as shown in Figure 3 above: 29.2\% of the students responding either agreed (16.7\%) or strongly agreed (12.5\%) that working in a randomly assigned group was a valuable experience. $50 \%$ of the students responding either disagreed (23.6\%) or strongly disagreed (26.4\%) that this aspect of the assignment was valuable; $20.8 \%$ of the students responding expressed no opinion on the question (neutral).

All thirteen students submitting additional comments on the group project spoke to the difficulty and frustration of coordinating the group work when students were not on campus for the summer. Ironically one student noted how difficult it was to collaborate because the students had to "communicate electronically." A few students noted it would have been easier to simply complete the assignment individually. No students commented on the "random" assignment of the members to the groups. We know that many students take the legal research course in the summer because of the flexibility the asynchronous online delivery gives them and because the credit load helps meet the financial aid requirements. Given this, I should have better prepared them for the nature of the group project by providing more specifics in the syllabus.

The text comments also reflect the student's perception that "online" courses are "solo" work and somehow incongruent with group work. I admit it was not something that I even considered as I have completed many online courses as a student and all of them involved group work across time zones, and 
in some cases, across continents. The syllabus clearly noted there would be a group project and included some basic parameters. In the future, it might be advisable to more fully describe the project.

It is apparent from the text comments that I overestimated my student's familiarity with the various online meeting options that are available to them. I incorrectly assumed that they would use the various options available to them as Indiana University students or alternatively, the free online alternatives. In the future the course materials will include information and tutorials on how to use these meeting technologies to meet "in person" to help them better manage this aspect of the project.

As noted in Figure 1 above, 57\% of the student responses indicated that the skills taught and assessed in the competitive intelligence unit will be of valuable to them. This indicates some pedagogical success, even though there is some tweaking to do with the design of the group aspect of the project. Given all the factors, overall the introduction of the group project into the online legal research course was successful.

We know that multiple-choice questions and citation questions "measure lower order cognitive skills in the remember and understand categories of Bloom's taxonomy." ${ }^{\prime 9}$ Therefore to determine if our students are learning the higher order practice-ready skills that we set out in our learning objectives, we need assessments that require students to "transfer knowledge through practice with real-life activities" (i.e., authentic assessments). ${ }^{70}$ The effectiveness of our instruction is measured by whether our students are really learning these higher order skills. I redesigned the competitive intelligence assessment because I believe that combining project problem-based learning and team work into an assessment that requires the delivery of work product requiring decision making at multiple levels (e.g., what to research, what information to include, and how to present the material) develops the higher order skills students need to be successful in their legal practices.

An authentic task is a "real world task or problem that the student would be expected to encounter in professional practice." ${ }^{\prime 11}$ Authentic assessments are "tasks [that] involve 'ill-structured' challenges and roles that help students rehearse for the complex ambiguities of the 'game' of adult and professional life."72 "Ill-structured challenges differ from assessments like multiple-choice tests in that they 'require disparate, often competing goals that . . . provide an opportunity to deal with the

\footnotetext{
${ }^{69}$ Beth Twomey, Authentic Assessments: Praxis for the Distance Librarian, 9 J. of Lib. \& Info. Ser. in Dist. Learn. 170 , 172 (2015).

70 Id.at 171.

71 Id.at 172.

72 Id. at 172 citing Grant Wiggins, The case for authentic assessment 3 (1990). Eric Digest. (ED328611)
} 
contingencies that real-world problems represent."'73 For an assessment to be authentic, students must be able to demonstrate their skill acquisition. ${ }^{74}$ In the competitive intelligence unit, students demonstrate their abilities by delivering quality work product that requires both legal aptitude and client management skills.

My main goals are to familiarize students with the concept of competitive intelligence and to provide them with a basic understanding of (i) which data to identify and locate, (ii) the importance of challenging and connecting the data, and (iii) how to organize and translate the data in to advice for the particular client or for use to develop business. In addition, a secondary goal is that students understand professionalism, standards for work product, and how to work on a professional team through their work on an authentic assessment that mimics real world work and working conditions. The redesigned competitive intelligence assessment using group work and peer evaluations fulfills these goals.

\section{The Next Level: Competitive Intelligence Instruction as a Simulation}

The opportunity to introduce our law students to business development and decision making skills via the competitive intelligence unit in the second year legal research course has been a successful curriculum expansion. Building on my legal research teaching experience and my experience teaching international LL.M. students using a flipped classroom, ${ }^{75}$ । was given the opportunity to design a competitive intelligence/corporate information simulation unit in our Advanced Legal Research (“ALR") course for the 2015-2016 academic year. The ALR course, which was previously taught online, is being redesigned as a two-credit graded hybrid simulation ${ }^{76}$ course by two law librarian colleagues and me. $^{77}$

${ }^{73}$ Id. at 172 citing J. Petraglia Reality by Design: The Rhetoric and Technology of Authenticity in Education 39 (1998).

${ }^{74}$ Id. at 175, citing J. Mueller, Assessing skill development, Nov/Dec. Libr.Media Connection 18, 18 (2008).

${ }^{75}$ See Lemmer, supra note 25 , discussing author's experiences teaching international LL.M students using the flipped classroom and problem-based learning labs.

${ }^{76}$ American Bar Association Standard 304(a) states: “(a) A simulation course provides substantial experience not involving an actual client, that (1) is reasonably similar to the experience of a lawyer advising or representing a client or engaging in other lawyering tasks in a set of facts and circumstances devised or adopted by a faculty member, and (2) includes the following: (i) direct supervision of the student's performance by the faculty member; (ii) opportunities for performance, feedback from a faculty member, and self-evaluation; and (iii) a classroom instructional component." ABA, Section of Legal Education and Admissions to the Bar, ABA Standards and Rules of Procedure for Approval of Law Schools 2014-2015.

${ }^{77}$ An Indiana University-Purdue University Indianapolis Center for Teaching and Learning - Curriculum Enhancement Grant (Redesigning Advanced Legal Research: Research for Deep Knowledge and Professional Skills) is funding the redesign of the ALR course. 


\section{The New ALR Course}

Rather than taking the traditional approach of simply providing more instruction on the legal information resources and topics covered in our first- and second-year legal research instruction, we are designing the course as a simulation. The semester-long course simulation will involve a publicly-traded utility facing the challenges and impact of new environmental statutes and regulations. The course will explore the issues the publicly traded utility faces in specific legal content areas - environmental and natural resources law, intellectual property, corporate law, and international law.

The 14-week hybrid course will consist of online instruction and in-person lecture and lab sessions. Before class, students will access online instruction, which will include text, screen casts, video, and podcasts. The in-class sessions will include brief review presentations by the instructor and the opportunity for student questions. The remaining in-class time will be problem-based learning lab sessions involving collaborative work under the guidance of an instructor. ${ }^{78}$

\section{Competitive Intelligence Unit in the New ALR Course}

The ALR course will include eight hours of competitive intelligence instruction. This additional time provides the opportunity to step back and delve deeper into decision making and business development using real corporate documents in the context of competitive intelligence instruction. The increased time also allows for a more complex and challenging authentic assessment. Each in-class session will include a related problem-based learning exercise that will be completed during the lab portion of the class session. The ability to practice and receive feedback is critical to the development of legal skills, and the exercises will include immediate peer and instructor feedback. ${ }^{79}$

The capstone project for this unit will be an 8-10 minute presentation on a publicly-traded corporation. The students will serve as legal teams with members randomly assigned for this project. The audience will include a member of the local bar who will serve as the general counsel of a corporation (the "GC") interested in doing business with or merging with the corporation. The presentation will include not only a corporate profile, but also advice to the client to proceed or withdraw from the proposed business transaction. In addition, the instructors will serve as corporate personnel. As in real life, the GC and the corporate personnel will interrupt to ask questions and challenge the advice given by the student team. There will be no right answers. The student team will need to think both analytically and creatively to identify the best option, not necessarily the right answer, and to advise the client.

\footnotetext{
${ }^{78}$ See Lemmer, supra note 25, at 481-483, discussing problem-based learning labs and active learning.

${ }^{79}$ William D. Henderson, Supercharging Lawyer Development Through Feedback, NALP BULLETIN 12 (June 2014$)$.
} 
The following outline describes generally the topics to be covered in the competitive intelligence unit in the new ALR course.

\section{Topic One: Critical Thinking Skills}

Description: "Thinking" is actually a skill that can be learned and improved. This requires some understanding of how individuals process and react to information. Developing and improving thinking skills is a life-long activity for all and especially for those entrusted with guiding and assisting others in resolving their legal matters.

\section{Topic Two: Corporate Organizational Documents}

Description: Use corporation organizational documents to discuss statutory requirements, good standing, and on-going corporate operations.

\section{Topic Three: Financial Accounting Basics}

Description: Use actual financial statements to cover general accounting concepts such as balance sheet, income statement, consolidated financial statements, equity, liabilities, cost accounting, GAAP, ROI, EPS, etc.

\section{Topic Four: Securities and Exchange Commission Documents}

Description: Use Securities and Exchange Commission filings to discuss statutory and regulatory reporting requirements.

\section{Topic Five: Corporate Ownership \& C-Suite and Senior Executives}

Description: Discuss and investigate share ownership, classes of stock, and other stock issues. Locate information on relationships, salaries and other biographical information.

Topic Six: News, benchmarking and other resources

Description: How to use what you can find; and where to find it.

\section{Topic Seven: Business Development Wrap Up}

Description: Business development will be part of every topic, but will include a wrap-up.

\section{Assessment: Company Profile Presentations}

Description: In an 8-10 minute presentation to a member of the local bar, who will serve as General Counsel for the client, students will advise the GC whether to proceed or withdraw from a proposed business transaction. . Students may use professional software of their choice in the presentation.

There is no one right answer for developing practice ready legal professionals. As Fanlund writes, the

"skills that graduating law students most need depend on the type of work they pursue and the abilities

they had prior to entering law school.." ${ }^{\prime 80}$ A unit on competitive intelligence enhances the decision making and business development skills all law students will need to be successful practitioners. The added

\footnotetext{
${ }^{80}$ Fanlund, supra note 24 , at 9.
} 
benefit for those students interested in legal careers outside the courtroom, or for those whose courtroom interest lies in commercial litigation, is the corporate and transactional context.

\section{Conclusion}

I may be one of the anomalies in Professor Watson's research and conclusions. ${ }^{81}$ My route to the legal academy came as a result of a series of right-angle resume turns that often happen in two-career families. I practiced as a corporate and transactional attorney for nearly ten years, and my years in practice were intellectually challenging and satisfying. I worked on interesting and challenging transactions, often for international clients. Once a colleague came into the conference room in the post-midnight hours, when we were all a little ragged, and said, "Catherine, we are nothing more than truck mechanics. We take it all apart, put it back together a little differently, and just hope there aren't any pieces lying on the floor when we are all done." That story has stayed with me long after I've left the practice. It is a perfect reminder that successful lawyers are both legal analysts and pragmatists and in all instances attune to their client's needs.

Lawyers are practitioners who work to resolve a client's legal issues - to resolve legal issues, she or he must have the requisite legal knowledge, skills training, and professional acumen. The difference in how law students evaluate their level of preparedness for practice compared with how practicing lawyers who work with these same law students rate their preparedness, suggests we are not developing the right skill sets and professional acumen in our law students. The addition of competitive intelligence instruction, particularly in the form of a simulation that works as an authentic assessment, responds to students' need for executive thinking and decision making skills in the corporate and transactional context. Competitive intelligence instruction using authentic assessments is one option to develop practice-ready legal professionals who are well versed in business development and networking and ready to contribute to the financial well-being of the firm.

\footnotetext{
${ }^{81}$ Newton, supra note 51, at 130 citing Watson at 29.
} 